\title{
Maternal Anxiety and Depression and Development of Prematurely Born Infants in the First Year of Life
}

\author{
Ana Emilia Vita Carvalho, Francisco Eulógio Martinez, \\ and Maria Beatriz Martins Linhares \\ Universidade de São Paulo (Brazil)
}

\begin{abstract}
The purpose of this study was: (a) to assess and to compare anxiety and depression symptoms in mothers of preterm neonates during hospitalization in the Neonatal Intensive Care Unit, after discharge, and at the end of the infants' first year of life; and (b) to assess the child's development at 12 months of chronological corrected age (CCA). Thirty-six mothers, with no psychiatric antecedents assessed with the SCID-NP, were evaluated by STAI and BDI. The infants were assessed with Bayley-II Scales. There was a significant decrease in clinical symptoms of state-anxiety in mothers $(\mathrm{p}=.008)$, comparing the period during hospitalization and after discharge of the infants. Clinical symptoms of anxiety and depression were observed in $20 \%$ of the mothers at the end of the infants' first year of age. The majority of the infants exhibited normal development on Bayley-II at 12 months CCA; however, $25 \%$ of the infants displayed cognitive problems and $40 \%$ motor problems. The mothers' anxiety and depression symptoms decreased at the end of the first year of life of the pre-term infants and the children showed predominately normal development at this phase.

Keywords: pre-term, very low birth weight, anxiety, depression, development
\end{abstract}

\begin{abstract}
El objetivo de este trabajo fue: (a) evaluar y comparar los síntomas de ansiedad y depresión en madres de neonatos pre-término durante su hospitalización en la unidad de cuidados intensivos de neonatos, después de su alta, y al cabo del primer año de vida de los niños; y (b) evaluar el desarrollo de los niños a los 12 meses de edad cronológicamente corregida (CCA). Se evaluaron a 36 madres, sin antecedentes psiquiátricos según el SCID-NP, con el STAI y el BDI. Los niños se evaluaron con las Escalas Bayley-II. Se observó una reducción significativa en los síntomas clínicos de ansiedad-estado en las madres $(p=.008)$, comparando el período durante la hospitalización y después del alta de los niños. Se observaron síntomas clínicos de ansiedad y depresión en el $20 \%$ de las madres al final del primer año de vida de los niños. La mayoría de los niños exhibieron un desarrollo normal en el Bayley-II a los 12 meses (CCA); sin embargo, el 25\% de los niños exhibieron problemas cognitivos y el $40 \%$ problemas motores. Los síntomas de ansiedad y depresión de las madres se redujeron al final del primer año de vida de los niños pre-termino y los niños mostraron un desarrollo predominantemente normal en esta fase. Palabras clave: prematuros, muy bajo peso al nacer, ansiedad, depresión, desarrollo
\end{abstract}

The authors would like to thank the mothers who agreed to participate in the study; the researcher, Flávia Helena Pereira Padovani (Doctorate student in Psycholog at FFCLRP-USP) and Luciana Leonetti Correia (Master's student in Mental Health at FMRP-USP) for collaborating in the collection of data; the team and administration of the Neonatalogy Sector at the Hospital of Clinical at the School of Medicine at Ribeirão Preto, University of São Paulo. The study was conducted with the support from the Fundação de Apoio ao Ensino, Pesquisa e Assistência at the Hospital of Clinical-FMRP/USP (Foundation for Support of Teaching, Research and Assistance). The Conselho Nacional de Desenvolvimento Científico e Tecnológico (National Council for Scientific and Technological Development - CNPq) supported the third author with a Grant for Productivity in Research.

Correspondence concerning this article should be addressed to Profa Dra Maria Beatriz Martins Linhares, Laboratório de Pesquisa - Prevenção de Problemas de Desenvolvimento e Comportamento da Criança (salas 52/53), Avenida Tenente Catão Roxo, 2650, Prédio da Saúde Mental - Faculdade de Medicina de Ribeirão Preto-USP, Campus Monte Alegre - USP, Ribeirão Preto - São Paulo (Brazil). Phone: (16) 3602-4610. E-mail: linhares@fmrp.usp.br; anaevc@terra.com.br

How to cite the authors of this article: Carvalho, A.E.V., Martinez, F.E. and Linhares, M.B.M. 
With technological and scientific advances in the area of medicine, there has been a progressive and significant increase in the rate of survival of infants born pre-term with severe low birth weight (Holmgren \& Högberg, 2001). The prematurity and birth weight under $1,500 \mathrm{~g}$ are identified as factors of biological risk for development that may also bring psychological complications both in the early relationship between the mother and the child, and for the baby's psychological development (Davis, Edwards, Mohay \& Wollin, 2003; Laucht, Esser, \& Schmit, 1997; Linhares et al., 2000; Linhares et al., 2004).

Pre-term birth and subsequent hospitalization of the baby in the Neonatal Intensive Care Unit (NICU) are considered a «psychological crisis» situation for the family causing feelings of anxiety and depression, mainly for the mothers (Allen et al., 2004; Davis et al., 2003; Padovani, Linhares, Carvalho, Duarte, \& Martinez, 2004; Zanardo \& Freato, 2001).

Studies show a high incidence of symptoms of depression in a sample of mothers of infants born pre-term (Orr, James, \& Prince, 2002; Padovani et al., 2004; Zanardo \& Freato, 2001). Davis et al. (2003) in a study with mothers of premature infants, $40 \%$ of the mothers exhibited symptoms of depression in comparison with a normal population of $15 \%$, considering that the high percentage of mothers exhibiting symptoms of depression occurs for them during the acute phase of hospitalization of the baby.

The premature birth at severely low weight is a condition perceived by the mothers as extremely inducive to anxiety and expectations permeated with fear and ambivalent feelings (Doering, Moser, \& Dracup, 2000; Grimstad, Schei, Backe, \& Jacobsen, 1999; Linhares, Chimello, Bordin, Carvalho, \& Martinez, 2005; Padovani et al., 2004; Zanardo \& Freato, 2001).

Technological advances and improved understand of physiopathology of neonatal problems have reduced the mortality rate in these children. Following these advances, a preoccupation has arisen regarding the impact of the NICU environment on the development of the baby (Als, 1982; Linhares et al., 2004; Peters, 1999) In a certain way, the developmental care of the baby should begin early in the period of internment in the NICU, which is the first micro-system to which the baby is exposed (Blackburn, 1998; Linhares, Carvalho, Bordin, \& Jorge, 1999; Pedromônico, 2001).

Studies indicate that 10 to $15 \%$ of children born under the condition of prematurity exhibit later complications in their overall development (Carvalho, Linhares, \& Martinez, 2001; Mancini et al., 2002; Melnyk et al., 2001).

The objectives of this longitudinal prospective study are: (a) to evaluate and compare clinical indications of anxiety and depression in mothers of babies born pre-term with low birth weight in three different moments, during internment in the NICU, after hospital release of the baby, and in the end of the first year of the baby's life; (b) to verify the relationship between the baby's indicators and neonatal variables with the mother's socio-demographic variables; and (c) to evaluate the psychological development of the babies in the end of their first year, and verify associations with the baby's and mother's characteristics.

\author{
Method
}

\section{Participants}

The sample of convenience, which participated in the study sample of Carvalho (2005), was composed of 36 mothers of recently born pre-term infants with low birth weight and interned in the Neonatal Intensive Care Unit (NICU) at the Hospital of Clinical at the School of Medicine of Ribeirão Preto at the University of São Paulo (HCMFRPUSP), in the period between 2001 and 2003. The study in question was conducted in a third-level health care university hospital by the Public Health System that included multidisciplinary care in which the mothers received psychological support during the period in which the baby was interned in the NICU. The inclusion criteria for the study were as follows: mothers of babies born with less than 37 weeks of gestational age, with birth weight equal or below 1,500 grams, and interned in the NICU.

The initial sample was composed of 61 mothers, within which 25 were excluded by the criteria adopted: (a) psychiatric history identified by the Structured Clinical Interview by DSM III-R-Non patient (SCID-NP) $(n=11)$; (b) illiteracy $(n=3)$; (c) positive diagnosis, according to information from the patient and laboratory exams, for the human immunodeficiency virus (HIV) $(n=1)$, in that this could constitute a potential source of anxiety; (d) maternal hospitalization in NIC $(n=1)$. The exclusion criteria for the babies entailed: release from the NICU during the maternal evaluation process $(n=6)$ and death while in the NICU $(n=3)$. All mothers gave consent for their participation in the study. A sample loss of $44 \%(n=16)$ was recorded after release from the hospital for the 12 months CCA stage. Each participant in the study signed a free and clear consent form, approved by the Ethics Committee of the Hospital of Clinical of the Ribeirão Preto School of Medicine (Process HCRP nr. 1607/2001).

\section{Instruments and Measures}

Structured Clinical Interview by DSM III-R-Non Patient Edition (SCID; Spitzer, Williams, Gibbon, \& First, 1990; translation by Del Ben, 1995), semi-structured interview script to investigate psychiatric disorders in individuals not identified as psychiatric patients.

The State-Trait Anxiety Inventory (STAI; Spielberger, Goursuch, \& Lushene, 1970; translated by Biaggio \& Natalício, 1979) is made up of two self-evaluation subscales: State-Anxiety and Trait-Anxiety.

The Beck Depression Inventory (BDI; Beck, Rush, Shaw, \& Emery, 1979; translated by Cunha, 2001), composed of 21 categories of symptoms and attitudes.

A Questionnaire for the Characterization of Mothers in the Neonatal ICU, interview script intended to collect information on socio-demographical data from the sample. 
The Bayley-II Scale of Infant Development (Bayley, 1993; translated by Barbosa, 2004), evaluates children's development from one to 42 months of age, and is composed of three scales: Mental Scale (178 items), Motor Scale (111 items), and Behavior Scale.

The Clinical Risk Index for Babies (CRIB; Cockburn et al., 1993) for identification of the neonatal clinical risk index.

The infant's medical records were also consulted.

\section{Procedure}

\section{Data Collection}

\section{1st instance - During internment of the baby at the Neonatal ICU.}

First contact was established with the mother, after the baby's birth, in which the mothers were invited to participate in the study. One agreement from the mothers was established, the contract for participation, via the free and clear consent form, approved by the Ethics Committee at the Hospital of Clinical at FMRP. Then, the SCID-NP was applied by the researcher (first author) to identify mothers with indicators of psychiatric history, who were excluded from the study.

A meeting was scheduled with the mothers who met the criteria for composition of the sample for psychological evaluation of indicators for anxiety and depression. To counterbalance the interference from application of one test over the other, a balancing was executed, alternative the order of the application of the BDI and STAI evaluation instruments. In the state-anxiety evaluation, the mothers were asked to focus on the current situation of the babies hospitalization in the NICU. The evaluations were conducted by two specialized psychologists with training in psychological evaluation. To the mothers were offered the option of reading and filling out the questionnaires alone after explanation, or with the assistance of the psychologists to read the questionnaires for them. Independent of this choice made by the mothers, their questions were clarified at any time if they requested assistance.

2nd instance - Baby's release from hospital. After the babies were released from the hospital, the mothers were reevaluated by the evaluating psychologists for emotional indicators of anxiety (STAI) and depression (BDI). This stage in the reevaluation of the mothers was conducted in the first appointments for the baby in the Longitudinal Follow-Program for Infants Born Preterm with Very Low Birth Weight (follow-up), which varied from one to two weeks following the baby's release from the hospital.

3rd instance - At 12 months of chronologically corrected age for the babies. The 3rd instance occurred at 12 months of chronologically corrected age for the babies. On this occasion, the researcher (first author) evaluated the babies' development using the Bayley-II Scales, and reevaluated the mothers' emotional indicators using the STAI and the BDI. In a later meeting, a feedback session was conducted with the mothers based on the results of the evaluation of the babies' development, in which referrals were made if necessary.

\section{Data Analysis}

The data from the instruments was analyzed according to their respective standards. In the STAI for identification of mothers with a score indicating anxiety, a statistical criterion was used for scores equal to or greater than the 75th percentile. A standardized measurement for anxiety at an intermediary level (high school) was used. On the StateAnxiety subscale, the mothers were asked to respond to the items while thinking of the situation of their child's birth. On the BDI, the criterion of scores greater than 20 for depression was used, suggested for non-diagnosed patients (Gorestein \& Andrade, 2000).

Statistical treatment included a descriptive analysis of the data in terms of frequency, percentage, and average, according to the nature of the data. Then, the data were analyzed by the Kolmogorov-Smirnov normality test to facilitate the decision regarding the statistical treatment adopted.

For analysis of the within-group comparison for maternal emotional indicators in the two initial instance of data collection was used the McNemar test for postpartum samples. To correlate performance on the Bayley-II Scales with the maternal variables (emotional indicators for stateanxiety, trait-anxiety, depression, academic level, number of children) and infant variables (birth weight, gestational age, duration of internment in the NICU, total duration of hospitalization, and CRIB score), Spearman or Pearson correlation tests were used. The data were tabulated and analyzed using the Statistical Package for Social Sciences - SPSS 12.0 for Windows. The significance value adopted was $5 \%(p \leq .05)$.

\section{Results}

Table 1 shows the socio-demographic characteristics of the mothers and neonatal characteristics of the babies. The data reveal that the sample was composed of young mothers with a low educational level, predominately at the elementary level. The majority of the mothers were first time mothers, were involved in stable conjugal relations, and worked at home, without pay. The average birth weight of the babies was 1,058 grams, while the average gestational age was 30 weeks. The Apgar index revealed a good prognosis for clinical development and a low neonatal clinical risk index. Internment in the NICU lasted around 31 days, and total duration of hospitalization prior to release lasted up to 72 days. 
Table 1

Socio-Demographic Characteristics of the Mothers and Characteristics of the Babies in the Neonatal Period

\begin{tabular}{|c|c|}
\hline Variables & Values \\
\hline \multicolumn{2}{|l|}{ Maternal } \\
\hline Age (years) $M(S D)$ & $24.56( \pm 6.81)$ \\
\hline \multicolumn{2}{|l|}{ Educational level (years of study) $n(\%)$} \\
\hline 8 years (elementary school) & $26(72 \%)$ \\
\hline 11 years (high school) & $10(28 \%)$ \\
\hline \multicolumn{2}{|l|}{ Marital status $n(\%)$} \\
\hline Single & $9(25 \%)$ \\
\hline Stable relationship / Married & $27(75 \%)$ \\
\hline \multicolumn{2}{|l|}{ Occupation $n(\%)$} \\
\hline Home & $22(61 \%)$ \\
\hline Work (outside the home) & $14(39 \%)$ \\
\hline First time mother $n(\%)$ & $21(58 \%)$ \\
\hline Income per capita (reais) $M d$ (Min-Max) ${ }^{(1)}$ & $140,00(7.00-1,133.00)$ \\
\hline \multicolumn{2}{|l|}{ Babies } \\
\hline \multicolumn{2}{|l|}{ Gender $n(\%)$} \\
\hline Female & $18(50 \%)$ \\
\hline Male & $18(50 \%)$ \\
\hline Birth weight (grams) $M(S D)$ & $1,058( \pm 241.98)$ \\
\hline Gestational age (weeks) $M(S D)$ & $30.44( \pm 2.26)$ \\
\hline Apgar -5 th minutes (score) $\quad M(S D)$ & $8.67( \pm 1.31)$ \\
\hline Appropriateness for gestational age - PIG $n(\%)$ & $26(72 \%)$ \\
\hline Clinical risk index - CRIB (score) $M(S D)$ & $3.73( \pm 3.34)$ \\
\hline \multicolumn{2}{|l|}{ Neonatal Period } \\
\hline Duration of internment at NICU (days) $\quad M(S D)$ & $31( \pm 24.67)$ \\
\hline Total duration of hospitalization (days) $\quad M(S D)$ & $72( \pm 39.69)$ \\
\hline
\end{tabular}

Note. ${ }^{(1)}$ Current minimum salary $=\mathrm{R} \$ 180.00 . \mathrm{PIG}=$ Small for gestational age.

Table 2

Maternal Indicators of State-Trait Anxiety and Depression Assessed during the Baby's Hospitalization in the NICU, after Release from the Hospital, and at the End of the First Year of Life: Means and Standard Deviations of Scores, and Frequency (f) and Percentage (\%)

\begin{tabular}{|c|c|c|c|}
\hline $\begin{array}{l}\text { Maternal emotional indicators } \\
\text { (state-trait anxiety and depression) }\end{array}$ & $\begin{array}{l}\text { During internment } \\
\text { in the NICU }(n=36)\end{array}$ & $\begin{array}{l}\text { After baby's release } \\
\text { from the Hospital }(n=36)\end{array}$ & $\begin{array}{l}\text { At } 12 \text { months of chronologically } \\
\text { corrected age }(n=20)\end{array}$ \\
\hline \multicolumn{4}{|l|}{$\begin{array}{l}\text { Emotional Indicators Taken Together } \\
\text { (Anxiety and/or Depression) }\end{array}$} \\
\hline Clinical indicators - f $(\%)$ & $14 *(39 \%)$ & $8(22 \%)$ & $4(20 \%)$ \\
\hline \multicolumn{4}{|l|}{ Specific Emotional Indicators } \\
\hline \multicolumn{4}{|l|}{ State-Anxiety } \\
\hline Total score - $M(S D)$ & $49.19( \pm 15.39)$ & $41.83( \pm 15.23)$ & $39.79( \pm 13.19)$ \\
\hline Clinical indicators - f $(\%)$ & $12 * *(86 \%)$ & $4(50 \%)$ & $2(50 \%)$ \\
\hline \multicolumn{4}{|l|}{ Trait-Anxiety } \\
\hline Total score - $M(S D)$ & $45.08( \pm 14.59)$ & $42.08( \pm 16.89)$ & $39( \pm 16.34)$ \\
\hline Clinical indicators $-\mathrm{f}(\%)$ & $8(57 \%)$ & $7(88 \%)$ & $2(50 \%)$ \\
\hline \multicolumn{4}{|l|}{ Depression } \\
\hline Total score - $\quad M(S D)$ & $11.69( \pm 10)$ & $10.06( \pm 9.66)$ & $6.07( \pm 6.94)$ \\
\hline Clinical indicators $-\mathrm{f}(\%)$ & $8(57 \%)$ & $4(50 \%)$ & $2(50 \%)$ \\
\hline
\end{tabular}

$* p=.03 . * * p=.008$. 
Table 2 shows the evaluated maternal indicators for anxiety and depression. There was a significantly higher occurrence of mothers with clinical indicators for anxiety and/or depression together, and, specifically, that clinical indicators for anxiety of the state type during internment of the child in the NICU only in comparison with the time of release from the hospital. The percentage of mothers that exhibited clinical indicators for anxiety and depression remained low at the final instance at the end of the first year of their babies' lives.

Table 3 shows the correlation coefficients that were significant between the anxiety scores (State and Trait) and maternal depression, and between these and the maternal variables and those of the babies, respectively. The correlation between the emotional indicators and the maternal indicators, the less educated mothers exhibited higher levels of these emotional indicators. Beyond this, the mothers with a greater number of children exhibited higher levels of situational type anxiety.

Regarding the infant variables, it was verified that the mothers whose babies had lower birth weight, lower gestational age, greater neonatal risk, spent more time interned in the NICU, and were hospitalized for longer periods exhibited higher levels of the situational/state type anxiety. Additionally, the mothers whose children were hospitalized for longer periods exhibited higher levels of trait/dispositional anxiety and depression.

Table 4 brings together the classification of the children's development at 12 months of chronologically corrected age, according the Bayley-II Scales. The results from the evaluation of development at the end of the first year of the 20 babies in the sample that remained in the study, there was a greater percentage of babies that exhibited normal performance for the CCA at 12 months in both the Mental Scale and the Motor Scale. It was verified that $25 \%$ of the babies had poor performance in the Mental Scale and 30\% with significantly impaired performance on the Motor Scale.

On the Behavioral Scale, the majority of the babies attained general development scores within normal parameters at 12 months of CCA. In the Orientation/Engagement and Emotional Control subscales, the majority of the babies exhibited development within normal parameters. However, in the Motor Quality subscale, a significant portion of the babies exhibited development consider «non-optimal» according to the standards for the Scale.

Table 5 shows the results from the coefficients from correlation between the Bayely-II Scale scores at 12 months of chronologically corrected age for the babies. There was a positive significant correlation between the results of the Mental, Motor, and Behavioral Scales, as well as in the Orientation/Engagement, Emotional Control, and Motor Quality subscales. This indicates that the children with greater impairment in their mental performance exhibited more motor and behavioral problems.

No significant correlations were found between scores on the Bayley-II Scales and the infant variables, related to health problems confronted in the neonatal phase and in the phase at 12 months of chronologically corrected age, and the maternal variables for anxiety and depression.

Table 3

Significant Pearson / Spearman Correlation Coefficients between Anxiety and Depression Scores and Maternal and Babies' Variables

\begin{tabular}{|c|c|c|c|}
\hline Emotional Indicators & Maternal Variables & $r$ & $p$-values \\
\hline \multirow[t]{2}{*}{ State-Anxiety } & Academic level (grade) ${ }^{(1)}$ & -.33 & .05 \\
\hline & Number of children (2) & .35 & .03 \\
\hline Trait-Anxiety & Academic level (grade) ${ }^{(1)}$ & -.44 & .008 \\
\hline Depression & Academic level (grade) ${ }^{(1)}$ & -.40 & .02 \\
\hline Emotional Indicators & Neonatal Variables & $r$ & $p$-values \\
\hline \multirow[t]{5}{*}{ State-Anxiety } & Birth weight (grams) ${ }^{(1)}$ & -.53 & .001 \\
\hline & Gestational age (1) & -.34 & .04 \\
\hline & Duration of internment in $\mathrm{NICU}^{(1)}$ & .46 & .005 \\
\hline & Total duration of hospitalization (1) & .46 & .004 \\
\hline & CRIB (1) & .37 & .03 \\
\hline Trait-Anxiety & Total duration of hospitalization (1) & .37 & .03 \\
\hline Depression & Total duration of hospitalization & .36 & .03 \\
\hline
\end{tabular}

Note. (1) Pearson's correlation test, (2) Spearman's correlation test. 
Table 4

Classification of Babies' Development at 12 Months of Chronologically Corrected Age via the Bayley-II Scale of Infant Development $(N=20)$

Bayley-II Infantile Development Scales Frequency

Percentage (\%)

Mental Scale

Normal performance

15

5

75

Poor performance

Motor Scale

Accelerated performance

Normal performance

1

11

Poor performance

Significantly impaired performance

Behavioral Scale (general score)

Within normal parameters

Questionable

Non-optimal

Areas:

Orientation/Engagement

Within normal parameters

Questionable

Non-optimal

Emotional control

Within normal parameters

Questionable

Non-optimal

Motor quality

Within normal parameters

Questionable

Table 5

Significant Pearson Correlation Coefficients between Scores on the Bayley-II Scale of Infant Development at 12 Months of Babies' Chronologically Corrected Age

\begin{tabular}{llll}
\hline Bayley-II Scales & Variables & $r$ & $p$-value \\
\hline Mental Scale & Motor Scale & .60 & .005 \\
Mental Scale & Behavioral Scale (general score) & .55 & .01 \\
& Orientation/Engagement & .59 & .006 \\
& Emotional control & .04 \\
Motor Scale & Motor quality & .45 & .01 \\
& Behavioral Scale (general score) & .55 & .003 \\
& Orientation/Engagement & .63 & .02 \\
& Emotional control & .51 & .02 \\
& Motor quality & .50 & .0001 \\
\hline
\end{tabular}




\section{Discussion}

The findings from this study show that, despite the median score for state-type anxiety being similar to that of the standardized sample for the STAI at the three instants (during internment of the child, after release, and at the end of the first year), when the score for clinical levels (above 75th percentile) is analyzed, which requires intervention for its standardization, differences were found between the moments of internment and after release from the hospital.

We verified that, while the premature infant was in the NICU, 39\% of the mothers exhibited symptoms of anxiety and/or depression at clinical levels. Additionally, when statetype anxiety was specifically considered, we noted an index of $86 \%$ of the mothers with clinical symptoms for anxiety focused on the situation of the premature birth of their child.

After the baby's release from the hospital, there was a significant decrease in the number of mothers with clinical emotional symptoms of anxiety and/or depression together $(22 \%)$ in relation to the time that the child was held in the hospital, as well as in the number of mothers with clinical symptoms specific to the state-type anxiety (50\%). It is supposed that the mother's level of stress tends to increase or decrease according to the baby's clinical condition (Grimstad et al., 1999; Orr et al., 2002; Padovani et al., 2004), in the findings from this study, we verified that the emotional state of the mothers with clinical symptoms for situational anxiety decreased in the level of anxiety as the baby developed favorably for release from the hospital.

It was verified that a portion of the mothers in this study exhibited indicators for trait-anxiety $(57 \%)$ and depression (57\%) during their child's internment in the NICU. Studies have emphasized that other variable present in the maternal environment may favor these emotions, or that these emotions may exist prior to the baby's birth (Orr et al., 2002; Allen et al., 2004). Exposure of the mother to multiple and continuous adverse events, not only the premature birth of their child, may contribute to the increase in levels of stress, and, consequently, the clinical levels of maternal emotional symptoms (Davis et al., 2003; Zanardo \& Freato, 2001). For example, in this study, the less educated mothers and those with a greater number of children were more anxious and depressed. In this manner, we verified that the present of other psychosocial risks may contribute to the increase in levels of stress in the mothers of premature babies, increasing the clinical levels of anxiety and depression.

In reference to indicators for depression, the Canadian Mental Health Association verifies that $3 \%$ to $20 \%$ of first time mothers experience episodes of postpartum depression. Davis et al. (2003) who evaluated 62 couples whose babies were born with less than 32 weeks of gestational age and were admitted to the NICU, found that $40 \%$ of mothers with depressive symptoms after birth when compared to the normal population, whose index is only $15 \%$. Our findings indicate a higher index for depression when compared with the population data and those found by Davis et al. (2003) in a sample of mothers with prematurely born infants.

In the follow-up of the prematurely born infants, after a year of live the maternal emotional indicators for anxiety and depression were evaluated, as well as the babies' development. From the 36 babies participating in the initial sample, 20 baby-mother pairs participated in the Longitudinal Follow-up Program for Infants Born Preterm with Very Low Birth Weight up to one year of age. In this occasion, only $20 \%$ of the mothers exhibited emotional indicators at a clinical level, with the symptoms analyzed both together and individually for anxiety and depression. A decrease in the portion of mothers exhibiting emotional clinical indicators was verified at the end of the first year of the baby's life.

In relation to the evaluation of the babies' development, using the Bayley-II Scale of Infant Development, the majority of the babies exhibited development within normal parameters at 12 months of CCA. On the Mental Scale, $75 \%$ of the babies exhibited normal cognitive performance. This data may be related to the presence of some maternal variables found in this context, such as the decrease in clinical levels of StateAnxiety after the baby's release from the hospital and continuing to the end of the first year of life, functioning as a protection mechanism activating maternal and environmental resources favoring the baby's cognitive development.

On the Motor Scale, 55\% of the babies exhibited normal motor performance, $30 \%$ had significantly impaired performance, and $10 \%$ exhibited impaired motor performance. On the Behavioral Scale, $60 \%$ of the babies exhibited normal performance, and $40 \%$ indicated behavioral problems. It was verified that the type of problem was predominately related to motor quality. In a Brazilian study in which 365 children were evaluated with the Bayley-II Scales, the authors verified that malnutrition, parasitic infections, the mother's academic level and mental health all had significant impact on the child's development (Santos et al., 2002). Despite technological advances having increase the survival rate of these babies, around 10 to $15 \%$ of them exhibit significant affects later in their development (Melnyk et al., 2001; Carvalho et al., 2001). Excessive exposure of the babies to the NICU environment and clinical interconcurrences experienced by the premature infants may contribute to an increase in developmental problems (Als, 1982; Linhares, Carvalho, Machado, \& Martinez, 2003; Peters, 1999).

In this study, we verified that the problems fall more in the area of motor development than in the mental area at the end of the first year of life, and it is important to note that the motor development exhibits an accelerated rhythm at this stage in an infant's life. In an at-risk population, the difficulty is not always in the neuro-motor components (tone, postural control, primitive reflexes). The compromised motor function may be related to the capacity to effect functional transferences and to move spontaneously within the environment, and in the ability to perform routine activities and task (Mancini et al., 2002). 
Two explicative hypotheses may be suggested by the motor damage observed in this group of babies. First, the baby's exposure to greater neonatal vulnerability and health complications appears to have an effect on motor performance in the studies sample. Second, the most anxious mothers appear to have greater difficulty in allowing the child to explore the home environment, such as, not permitting the child to be left on the floor, thus limiting the child's movements and impeding their motor organization and exploration of their environment (Carvalho et al., 2001; Linhares et al., 2003).

The findings of this study demonstrate that the period from the baby's birth up to release from the hospital is a particularly sensitive time for the mother's emotional balance. Early psychological intervention is, thus, recommended, centered on the mother during the baby's hospitalization in the NICU. After the baby is release from the hospital, the follow-up program should have a double function, to evaluate the baby's development, and to monitor the mother/caregiver's emotional state, in so far as this entails a new situation in which security is demanded of them in the care of the baby. The follow-up programs focus on the baby and the mother, for the purpose of promoting support and adjust the mother's perception in relation to the baby's development (Doering et al., 2000; Linhares et al., 1999; Linhares, Carvalho, Correia, Graspardo, \& Padovani, 2006; Pedromônico, 2001; Pridham, Lin, \& Brown, 2001).

Some considerations must be made in relation to this current study. Due to the study being conducted in a context of assistance, the scheduling of the data collection session had to be adjusted according to the mothers' appearance in the hospital for the babies' check-ups, since the majority of the mothers resided in other cities and depended on public transportation. As such, the study sample is characterized as a sample of convenience.

There was a loss of $44 \%$ of the sample participants in the babies' follow-up in the first year due to family moves to another state, medical follow-up conducted in their home town, and lack of interest in participating in the follow-up. The study ended with 20 families that continued until the conclusion of the third stage. Sample loss is a real limitation in studies of the longitudinal-prospective design.

It may considered an advantage that the study was conducted in locus, or rather, in the very context of the baby's medical follow-up, and not in an artificial laboratory environment. This granted us contact with the mothers and longitudinal monitoring of the baby's development which gave the study ecological validity. It is recommended, nonetheless, to be cautious in generalizing the results found in this study in relation to infant development and standards of normality, considering that the children in this study participated in the follow-up conducted in a university hospital with multi-professional care for the premature baby. This fact may bring more favorable results than if the children did not have this follow-up condition.
Considering an applied unfolding of this study, psychological support is recommended for mothers of children born pre-term in the initial phase of the infant's internment in the NICU and continuing after release with follow-up programs intended to evaluate the baby's development and guide adequate social mediation of their development through their caretakers.

\section{References}

Allen, E.C., Manuel, J.C., Legaut, C., Naughton, M., Pivor, C., \& O'Shea, T.M. (2004). Prediction of child vulnerability among mothers of former premature infants. Pediatrics, 113, 266-273.

Als, H. (1982). Toward a synactive theory of development: Promise for the assessment and support of infant individuality. Infant Mental Health Journal, 3, 229-243.

Barbosa, A.F.C. (2004). Aplicação da escala Bayley de Desenvolvimento Infantil-II para avaliação de comportamento em crianças com carência nutricional. Master's thesis, Ribeirão Preto (SP): Universidade de São Paulo.

Bayley, N. (1993). The Bayley Scales of Infant Development $\left(2^{\text {nd }}\right.$ ed.). San Antonio, TX: The Psychological Corporation.

Beck, A.T., Rush, A.J., Shaw, B.F., \& Emery, G. (1979). Cognitive therapy of depression. New York: Guilford Press. (Portuguese translation: J.A. Cunha, Manual da versão em português das Escalas de Beck. São Paulo: Casa do Psicólogo, 2001).

Blackburn, S. (1998). Environmental impact of the NICU on developmental outcomes. Journal of Podiatric Nursing, 13, 279-289.

Carvalho, A.E.V. (2005). Indicadores emocionais maternos $e$ intervenção psicológica durante a internação do bebê prétermo em UTI Neonatal. Doctoral dissertation, Ribeirão Preto (SP): Universidade de São Paulo,

Carvalho, A.E.V., Linhares, M.B.M., \& Martinez, F.E. (2001). História do Desenvolvimento e Comportamento de crianças nascidas pré-termo e baixo peso $(<1500 \mathrm{~g})$. Psicologia: Reflexão e Críticas, 14, 1- 33.

Cockburn, F., Cooke, R.W.I., Gamsu, H.R., Greenough, A., Hopkins, A., Mcintosh, N., Agstont, S.A., Parryt, G.I., Silverman, M., Shaw, I.C.L., \& Tarnow-Modit, W.O. (1993). The CRIB (Clinical Risk Index for Babies) score: A tool for assessing initial neonatal risk and comparing performance of neonatal intensive care units. Lancet, 342, 193-198.

Davis, L., Edwards, H., Mohay, H., \& Wollin, J. (2003). The impact of very premature birth on the psychological health of mothers. Early Human Development, 73, 61-70.

Del Ben, C.M. (1995). Estudo da confiabilidade do diagnóstico psiquiátrico obtido através da Entrevista Clínica para DSMIII-R (SCID) em serviço ambulatorial de um hospital escola (Master's Thesis). Ribeirão Preto (SP): Universidade de São Paulo.

Doering, L.V., Moser, D.K., \& Dracup, K. (2000). Correlates of anxiety, hostility, depression, and psychosocial adjustment in parents of NICU infants. Neonatal Network, 19, 15-23. 
Gorestein, C., \& Andrade, L.H.S.G. (2000). Inventário de Depressão de Beck - Propriedades psicométricas da versão em português. In: C. Gorenstein, L.H.S.G, Andrade, \& A.W. Zuardi (Orgs.), Escalas de avaliação clínica em Psiquiatria e Psicofarmacologia (pp. 89-95). São Paulo: Lemos-Editorial.

Grimstad, H., Schei, B., Backe, B., \& Jacobsen, G. (1999). Anxiety, physical abuse, and low birth weight. Scandinavian Journal Public Health, 27, 296-300.

Holmgren, P.A., \& Högberg, V. (2001). The very preterm infanta population based study. Acta Obstetric and Gynecology Scandinavia, 80, 525-531.

Laucht, M., Esser, G., \& Schmit, M.H. (1997). Developmental outcome of infants born with biological and psychosocial risks. Journal Child Psychology and Psychiatry, 38, 843-853.

Linhares, M.B.M., Carvalho, A.E.V., Bordin, M.B.M., Chimello, J.T., Martinez, F.E., \& Jorge, S.M. (2000). Prematuridade e muito baixo peso ao nascer como fator de risco ao desenvolvimento psicológico da criança. Cadernos de Psicologia e Educação Paidéia, 10, 60-69.

Linhares, M.B.M., Carvalho, A.E.V., Bordin, M.B.M., \& Jorge, S.M. (1999). Suporte psicológico ao desenvolvimento de bebês prematuros com peso de nascimento abaixo de $1.500 \mathrm{~g}$ : na UTI Neonatal e no seguimento longitudinal. Temas em Psicologia da Sociedade Brasileira de Psicologia, 7, 245-262.

Linhares, M.B.M., Carvalho, A.E.V., Correia, L.L., Graspardo, C.M., \& Padovani, F.H.P. (2006). Psicologia Pediátrica em Neonatologia de alto risco: promoção precoce do desenvolvimento de bebês prematuros. In M.A. Crepaldi, M.B.M. Linhares, \& G.B. Perosa (Orgs.), Temas em Psicologia Pediátrica (pp. 109-146). São Paulo: Casa do Psicólogo.

Linhares, M.B.M., Carvalho, A.E.V., Machado, C., \& Martinez, F.E. (2003). Desenvolvimento de bebês nascidos pré-termo no primeiro ano de vida. Cadernos de Psicologia e Educação Paidéia, 13, 59-72.

Linhares, M.B.M., Carvalho, A.E.V., Padovani, F.H.P., Bordin, M.B.M., Martins, I.M.B., \& Martinez, F.E. (2004). A compreensão do fator de risco da prematuridade sob a ótica desenvolvimental. In E.M. Marturano, M.B.M. Linhares, \& S.R. Loureiro (Orgs.), Vulnerabilidade e Proteção Indicadores na Trajetória do Desenvolvimento Escolar (pp. 10-38). São Paulo: Casa do Psicólogo/FAPESP.

Linhares, M.B.M., Chimello, J.T., Bordin, M.B.M., Carvalho, A.E.V., \& Martinez, F.E. (2005). Desenvolvimento psicológico na fase escolar de crianças nascidas pré-termo em comparação com crianças nascidas a termo. Psicologia: Reflexão e Crítica, 18, 109-117.

Mancini, M.C., Teixeira, S., Araújo, L.G., Paixão, M.L., Magalhães, L.C., Coelho, Z.A.C., Gontijo, A.P.B., Furtado, S.R.C., Sampaio, R. F., \& Fonseca, S.F. (2002). Estudo do desenvolvimento da função motora aos 8 e 12 meses de idade em crianças prétermo e a termo. Arquivos de Neuropsiquiatria, 60, 446-452.

Melnyk, B.M., Alpert-Gills, L., Feinstein, N.F., Fairbanks, E., Schultz-Czarniak, J., Hust, D., Sherman, L., Le Moine, C., Moldenhauer, Z., Small, L., Bender, N., \& Sinkin, R. A. (2001). Improving cognitive development of low-birth-weight premature infants with the COPE program: a pilot study of the benefit of early NICU intervention with mothers. Research in Nursing \& Health, 24, 373-389.

Orr, S.T., James, S.A., \& Prince, C.B. (2002). Maternal prenatal depressive symptoms preterm births among African-American women in Baltimore, Maryland. American Journal Epidemiology, 156, 797-802.

Padovani, F.H.P., Linhares, M.B.M., Carvalho, A.E.V., Duarte, G., \& Martinez, F.E. (2004). Avaliação de sintomas de ansiedade e depressão em mães de neonatos pré-termo durante e após hospitalização em UTI Neonatal. Revista Brasileira de Psiquiatria, 26, 251-54.

Pedromônico, M. (2001). Avaliando o desenvolvimento. Arquivos de Neuropsiquiatria, 59, 16-17.

Peters, K. (1999). Infant handling in the NICU: Does development care make a difference? An evaluation review of the literature. Journal Perinatology Neonatal Nursery, 13, 1-28.

Pridham, K., Lin, C-Y., \& Brown, R. (2001). Mothers' evaluation of their caregiving for premature and full-term infants through the first year: contributing factors. Research in Nursing \& Health, 24, 157-169.

Santos, D., Pedromônico,, M. R. M., Rodrigues, L., Bastos, A. C., Almeida Filho, N., \& Barreto, M. L. (2002) Epidemiologia do desenvolvimento mental infantil: influência de aspectos individuais e contextuais. Revista Brasileira de Epidemiologia, 1,103 .

Spielberger, C.D., Gorsuch, R.L. \& Lushene, R.E (1970). Manual for the State-Trait Anxiety Inventory. Palo Alto, CA: Consulting Psychologist Press. (Portuguese translation: A. Biaggio \& L. Natalício, Inventário de Ansiedade Traço-Estado - IDATE. Rio de Janeiro: Centro Editor de Psicologia Aplicada, 1979).

Spitzer, R.L., Williams, J.B.W., Gibbon, M., \& First, M.B. (1990). Structured Clinical Interview for DSM-III-R-Non-Patient Edition (SCID-NP, Version 1.0). Washington, DC: American Psychiatric Press. (Portuguese translation: C.M. Del Ben, Ribeirão Preto (SP): Universidade de São Paulo, 1995).

Zanardo, V., \& Freato, F. (2001). Home oxygen therapy in infants with bronchopulmonary dysplasia: Assessment of parental anxiety. Early Human Development, 65, 39-46.

Received March 22, 2007

Revision received October 1, 2007 Accepted January 19, 2008 